\title{
Reflections on the Secularization Trend of Chinese Religions
}

\author{
Fujiang Sun \\ Department of Public Administration \\ University of International Relations \\ Beijing, China 100091
}

\begin{abstract}
With the method of comparative study, the paper starts from the influence of the changes of social and economic conditions on religions, researches the main causes of the religious changes in contemporary China's society, puts forward that the socialist market economy is the main basis of the secularization of religions in China. But the secularization of social life and religious secularization will not lead to the demise of religion.
\end{abstract}

Keywords-religion; secularization; Christianity; Islam; Buddhism; market economy

\section{INTRODUCTION}

Social consciousness is determined by social existence, and social consciousness changes with the development of social existence, which is the objective law of the development of human society. Religion, as a social consciousness, is no exception. As Plekhanov said: "the 'identical' religion essentially changes its content in order to adapt to the economic development for its adored ethnic groups." ${ }^{11}$ Taking Christianity for example, Initially, Christian adapted the slavery economy, and supported the slavery society. As the society developed from the slavery economy to the feudal economy, Christianity formed the feudal Christian class system in order to adapt to the feudal hierarchy. As the society developed from the feudal economy to the capitalist economy, Christianity adapted to the capitalist economy through religious reform, and became the governing tool of the capitalist class. After the establishment of the socialist economy, Christianity had a serious of fundamental changes in order to adapt to the socialist economy, and the majority of believers become the mass of the socialist construction.

Not only Christianity, in the long river of human history, but also many other religious exist and live till now. Some regional and national religions are revolved to world religions. The important reason it that these religions can adjust their doctrine, organization, rite and other contents with the change of social economic relations, so as to meet the requirements of the social and economic development.

Religion not only has the adaptability to the social and economic development, but also has the corresponding adaptability to other social conditions. In the late Ming Dynasty of Chinese history, Catholic Missionary Matteo Ricci made friends with $\mathrm{Xu}$ Guangqi and other literatus in order to adapt to China's cultural environment. In the same period, Trigault wrote Aid to the Eyes and Ears of Western Literati in order to adapt to China's language environment. In the late Ming Dynasty and early Qing Dynasty, an activity of Annotating Koran with Confucianism rose in Hui nationality who embraced Islam. It was to adapt to Chinese philosophy environment. There are many other examples.

The history has proved that religion has the internal adaptation mechanism to the development and change of social realistic conditions. This kind of adaptation mechanism is the internal basis of world religion trends and even the basis of religions in China to be secularized. The specific religious adaptability conditions in different countries to the social and economic development are also different. The paper will analyze the issue of religious secularization in China under the condition of market economy compared with world religious secularization.

\section{THE "SECULARIZATION" OF MODERN WORLD RELIGIONS AND ITS CAUSES}

In order to adapt to the formation and development of the capitalist market economy, "secularization" has become the trend of the modern world religions. "Secularization", namely "non- sacredness", "can be understood as an indifferent trend that the religion followers produce due to the attraction of social, economic and cultural life. It reduces the value of religion and results in the recession of its sacredness. Thus, religious followers start to care about secular events and return to real life. They ever pursued eternal heaven and the afterlife, but now they begin to face real society and their life. "2 Peter Berger, a famous contemporary American religious sociologist, called religious secularization as "the scarcity of sacredness"3.

Secularization is a historical process of the world. "Protestantism is the decisive pioneer in history of secularization." Under the social conditions of the capitalism replacing the feudal autocratic system, Protestantism has formed new doctrines through religious reforms in 16th century and 17 th century. Its doctrines not only talk about the future and the heaven, but also involve in many social realistic problems. Martin Luther advocated that Christians should serve God in earthly life and realize their own value in earthly life. Muntzer proposed "there is no so-called afterlife paradise", and "there is no so-called afterlife hell". The heaven should be built in real world. Calvin encouraged people to fight for 
themselves, and to pursue endless wealth. He said wealth was a sign of success for people who have received God's grace. He deemed that "it is to glorify God by transforming society and establishing the kingdom of God in this world" 5 . Martin Luther, Munzer and Calvin promoted the secularization of religion from doctrine, which has a profound influence on the secularized development of Protestantism and other religions in the world.

Liberal theology emerged in the late 19th century. It understood Jesus and his teachings from a rational and ethical point of view, and the role of Christianity with a positive and optimistic spirit of entering the world. A variety of new theological genres appeared in the 20th century, such as, empirical theology, process theology, feminist theology, black theology, secular theology, "God-is-dead" theology, and "nonreligion Christianity". They are all the result of religious secularization in modern diversified secular society. Catholic tried to resist the tide of modernization and secularization. But the Catholic reform requirements, since the 1960s, forced the Pope to issue a call of "catching up with the times" in the farreaching second public conference in Vatican. In recent years, the apology of the Vatican on the Galileo Affair and other behaviors are all performance of self-adjustment and religious secularization in modern world.

Compared with Christianity, Islam and Buddhism have different characteristics in secularization. Buddhism standing for moving away from the world positively participates in the deliberation and administration of state affairs in recent years. Monks are active in the political arena of the world and become a new rising political force in Buddhist countries. For Islam originally promoting to enter into the world, its secularization is more significant. As many Muslims believe modern Islam is very different from the Islam in the Muhammad era and the four-great-caliph era. Modern believers derive from the original doctrines of Prophet Muhammad, and Islam is attached to lots of things that were not in the original. These differences are the performance of the secularization of Islam.

Reviewing the development trend of modern world religions, traditional religions go from bad to worse. The indifference of religious theocracy, religious life democratization, morality of religious belief, and modernization of values become the trend of modern world religions.

The main causes of the secularization of world religions are: first, the bourgeois Enlightenment brought the appreciation of human reason, the rise of personal status and the strengthening of self consciousness. The human-centered social atmosphere has replaced the "god-centered" social atmosphere, so that religion, ever as main conduct rule, is devalued inevitably.

Second, after the bourgeois revolution, Oriental and Western society gradually become secularized. The separation of religion from politics is accepted by more and more countries. As all fields of society gradually get rid of the shackles of religion, and social institutions become increasingly rational, the traditional religions is bound to adjust themselves to adapt to the social secularization process.
Third, the development of the capitalist market economy has brought about the rapid development of science and technology and the realization of modernization. The prosperity of the secular life has reduced the status of God and traditional religion in the minds of people. 6

\section{THE MAIN MANIFESTATIONS OF CONTEMPORARY CHINESE RELIGIONS}

Like the world religious trend, under the condition of socialist market economy, "secularization" has become the main trend of contemporary Chinese religions.

The dominant ideology of Chinese traditional culture and education is positive to the world, and it attaches great important to humanity and belittles divinity, so religion has not occupied the dominant position. We have no religious fanaticism, like that in Western Europe and the Arab world. Therefore, Chinese religions more easily become secularized.

After the founding of new China, the religious secularization has slowly begun. All religions put forward new doctrines and ideas with the combination of socialist construction and real life. Islam put forward the doctrine that "we need to rely on both labor and the help of Huda (Allah) to gain happiness life", and called upon Muslims to actively participate in the practical construction of socialist and build a beautiful earthly "heaven". Christianity proposed the doctrine of "to love people is to love god", "loving country and church, and glorifying God and serving human beings" to call on believers to dedicate to all just causes. Buddhism proposed "to establish an earthly pure land with good intention towards others" and to establish a "Humanistic Buddhism", and called on Buddhists to build a realistic human paradise.

Since the reform and opening up, under the impact of the market economy, Chinese religion has accelerated the process of the secularization, and has its own unique form.

\section{A. Pursuit of Secular Life Is Higher Than that of Belief, Which Is One of the Manifestations of the Secularization of Contemporary Chinese Religions}

The development of the socialist market economy produces a huge economic force to promote people to work hard and improve efficiency. In the face of ruthless competition of market economy, religious followers had to first consider real life. When there are conflicts among their work, production and religious activities, they would rather give up religious life temporarily and put work and production first. ${ }^{7}$ In the egalitarianism era, religious followers had some leisure time to participate in religious life while they survived in the natural economy. But now, in order to gain more material wealth and improve the worldly life, they should treat religious activities as personal spiritual pursuit after worldly life.

Due to the stimulation of the remarkable improvement of modern material life, religious followers not only pursue illusory afterlife and visionary heaven, but also pursue a happiness lifetime in the world. As they say, as a believer, they hope to enter the kingdom of heaven; as a man, they look forward to the prosperity of our country and a good life. 
However, in the dual nature of belief, they pay more attention to the pursuit of secular life.

\section{B. The Introduction of the Secular Commodity Economic} Activities and Values Into the Religious Temple Is Another Manifestation of the Secularization of Contemporary Chinese Religions

Under the condition of socialist market economy, the secular commodity economic activities and the values have become the thought idea and the economic behavior of the majority of believers.

In the name of "self-sufficiency", Christianity builds economic entities and engages in various economic activities. Some local churches have established "three-self enterprises", "three-self stores" and "three-self hospitals". Some local churches play their traditional role in undertaking culture and education and science and technology to service the society. They build foreign schools, and hold training course on embroidery and sewing technology, computer operation and sports. All of them have received a good economic effect.

The commodity economic activity of Islam is more significant. Engaging in business is a long good tradition of Muslim. Now the incentive of the market economy brings them new vitality. Their traditional businesses and trades are everywhere in the country. The food industry of Muslim grows vigorously. Their trade caravans engaging in daily supplies and long-distance transport can be seen everywhere. The historical carriage teams have been transformed into modern auto operation. The traditional "broker houses" have become new "brokers". Muslims' emerging industries, such as economic and trade companies, real estate, finance companies, cultural and entertainment industries, small and medium manufacturing, have emerged one after another. Some famous mosques have carried out the tourism industry, and the benefits are considerable. 8

Buddhism, on the basis of leaving away from the world, is also very active in the tide of market economy. They changed their main religious life of cultivating their moral character and observing their doctrines, and the original Buddhism economy that manages landed property to maintain plain life. They transformed former solemn temples into profitable tourist sites and shopping malls. For example, the famous Shaolin Temple has become a profitable economic entity. The annual economic income of some temples even could be up to million yuan. Monks, ever upholding poor life, have become businessmen. According to reports and photos newly published by media, some monks set up stalls in the streets and female nuns drove taxi and engaged in passenger transport. They not only learn "Buddhist scriptures" well, but also do "business management" well. It has become an ideological concept of Chinese Buddhists.

\section{The Socialization and Emotionalization of Religious Morality Are the Third Manifestation of the Secularization of Contemporary Chinese Religions}

Religious moralities are conduct rules to adjust the relationship between believers and god, and among believers, with serving the religious theology as basic purpose. It is composed of two parts, sayings of god and humanity. The "sayings of god" are to adjust the relationship between god and believers. It pursues an ideological realm gained through belief. The absolute loyalty to god is the highest morality. The "humanity" is to adjust the relationship among believers. In fact, it is to sanctify secular morality adjusting relationship among people and include them into religion. For example, the Christian commandments, "Do not commit adultery, Do not kill, Do not steal, Do not bear false witness, Honor thy father and mother, Do not cover your neighbors' properties", are so. Buddhism and Islam also have the corresponding moral requirements.

Sayings of god and humanity are contradictory. Sayings of god are centered on god, so they are above humanity. Feuerbach said: "morality and religion, faith and love, are a direct contradiction. Anybody falling in love with God will no longer love anyone. He/she will lose all interests in the world".9 In fact, all different religious systems have ever persecuted pagans and waged religious wars for their gods. Religious followers used human sacrifice and self mutilation to show their devotion to gods. In Bible and Koran, Saint Abraham or Prophet Abraham attempted to sacrifice his son. It can be seen that to fear god is to injure man, and to follow sayings of god is to belittle humanity. In this point, Pragmatism Founder William James also said that: "a narrow heart can only hold one kind of feeling. If the feeling of loving god occupies this place, he/she will eliminate all his/her love to man and life". 10

In traditional religious morality, humanity is subjected to sayings of god. But under the condition of socialist market economy, sayings of god are subjected to humanity. The concepts of "God is supreme" and "God is the master of all" are replaced by the concept of "relying on both man and god". The concept of god is relatively weakened, and the religious mysterious effect is relatively lowered. The moral relationship between man and man gradually sublimates. The moral values adjusting the relationship between man and man gradually become the ideological realm of our religions. Religious humanity expands to social coverage. With the morality of "advising to be good", they promote charitable causes, establish hospital, carry out freely clinic, relieve famine and the poor, heal the wounded and rescue the dying. Religious followers take pleasure in helping others. They help orphans and widows in order to gain inner peace and prolong life. In the production and business activities, they advocate and adhere to integrity. The religious morality has produced a widespread social influence. It serves the society, and has become a part of social morality.

The traditional religious morality is the sanctification of religious morality. But now it is the emotionalization of religious morality. Friendship, honesty, support and trust among believers have surpassed the worship, fear and submission to god. Believers don't firmly trust god's existence and dignity, but pay more attention to emotional sustenance, expectations and communication. 


\section{The Main CAUSES OF THE SECUlarization OF CONTEMPORARY CHINESE RELIGIONS}

The main causes of the secularization of contemporary religions in China lie in: first, the development of socialist market economy has improved people's living standards, thereby enhancing followers' yearning for secular life and enthusiasm of secular interests and investment on modernization and interpersonal feelings.

Second, under the condition of socialist market economy, commodity economy activity and its value permeate in every field of social life, and religion is no exception. The essence of socialist market economy is fair competition and the survival of the fittest. It is very necessary for religion to participate in the activities of commodity economy in order to enhance the awareness of commodity, adapt to the socialist market economy, support the basic necessities of life, and get richer.

Third, the socialist market economy promotes the realization of socialist modernization. Under the condition of socialist market economy, it is very necessary for religion to establish enterprises, develop economy and strengthen the strength in order to adapt to the socialist modernization.

Fourth, the secularization of contemporary Chinese religions is also related to the secular trend of world religions. Under the condition of socialist market economy, the unique form of Chinese religious secularization is doubtlessly a specific reflection of the socialism with Chinese characteristics in the religious field. For all kinds of negative phenomena generated in the process of religious secularization, such as, religious people's disregard of religion reputation in production and operation, practicing fraud, cheat and abduction, and moral decay, we shall eliminate and wipe off them with socialist spiritual values and the rules of law.

\section{CONCLUSION}

Under the condition of market economy, secularization is the trend of modern world religions but also the main trend of contemporary Chinese religions. In addition to the internal reason that religion has adaptability to the change of social conditions, the religious secularization has other specific social causes. However, secularization will not lead to the demise of the religion, or make society with no religion. The religious secularization has a characteristic of "self-limitation". If the secularization of religion surpasses this certain limit, it will not be a religion.

\section{REFERENCES}

[1] Jiang Yayu, Liu Shiwen. Methods and Approaches for Improvement of Plekhanov. The Development of Monistic Conception of History, Sanlian Bookstore Publishing, March 1973.

[2] Lin Zhaorong. Explorations on Market Economy and Trend of Chinese Religions. World Religions Studies, No. 2, 1993.

[3] Peter Berger. Holy Curtain. Shanghai People's Publishing House, July 1991.

[4] same as [2].

[5] Gao Shining. Secularization and Religious Fanaticism. The Orient, April 1994.
[6] Feng Zenglie. Review on Current China's Religions and Development of Economy. Northwest National Study, No. 1, 1994.

[7] Feuerbach. Feuerbach Philosophy Anthology (Volume II). The Commercial Press, January 1984, Page 800

[8] James. Varieties of Religious Experience. The Commercial Press, June 1947, Page 366. 